\title{
Some responses of the root and the shoot of Vicia faba plants to water stress
}

\author{
A. H. El Nadi ${ }^{1}$, R. Brouwer and J. Th. Locher \\ Institute for Biological and Chemical Research on Field Crops and Herbage (IBS), \\ Wageningen, the Netherlands \\ Received 15 January 1969
}

\section{Summary}

Broad bean plants were grown at $15^{\circ}$ or $25^{\circ} \mathrm{C}$ in alternating wet and dry periods. Drying of the soil promoted deeper root growth. Total root weight was not affected. Shoots grew less with a dry treatment in both the vegetative and the flowering phase.

\section{Introduction}

We studied root growth of Vicia faba in soils with different moisture conditions during vegetative growth and flowering. We compared growth of aerial and subterranean parts in plants with different water treatments and measured transpiration. We hoped to explain why this crop is particularly sensitive to water stress during flowering. One explanation is that root growth is retarded during anthesis; thus water supplies to the root depend mainly on water movement through the soil to existing roots. But if roots continue to develop during flowering, the sensitivity to water stress during flowering must be due to another factor, perhaps to less efficient water transport through the plant.

\section{Materials and methods}

\section{The soil mixture}

To grow plants in containers, a potting compost is needed which is stable in structure. We used a mixture of peat 25 , sandy clay 35 and sand $40 \%$ (v/v). This compost did not seal at the surface; infiltration of added water and aeration of the soil were good throughout the trial. At field capacity the compost contained $70 \%(\mathrm{w} / \mathrm{w})$ water due to the high proportion of peat. Permanent wilting point (PWP) for broad bean plants (Vicia faba) was at $18 \%$ water in a growth chamber at $17^{\circ} \mathrm{C}$.

Perspex tubes and control of capillary rise of soil water

Perspex tubes $5.8 \mathrm{~cm}$ inside diameter and $66 \mathrm{~cm}$ long were closed below by tightly fitting rubber stoppers, through which holes were bored to drain off excess water. The tubes were packed with compost as follows. Small portions were added and the

1 Present address: Faculty of Agriculture, University of Khartoum, Khartoum North, Sudan. 
tube was gently tapped until the compost was $17 \mathrm{~cm}$ deep. Before packing more in, the compost was covered with $3 \mathrm{~cm}$ of clean small pebbles (about $0.5-0.8 \mathrm{~cm}$ diameter) and a thin sheet of glass wool. The pebbles prevented capillary rise of water from the wetter lower layers of soil, thus allowing high stress conditions in the upper layers. The glass wool prevented soil particles washing down from one layer to the next. Neither pebbles nor glass wool stopped roots growing through to the next layer of soil. The soil surface was covered with coarse grit to prevent breakage of soil structure and sealing of the surface (Fig. 1).

\section{Watering and water treatments}

The tubes were watered (more than once a day if necessary) by adding measured amounts of water to the surface when soil moisture reached a certain value. Representative tubes and their contents were weighed before and after watering.

The plants were subjected to wet (W) or dry (D) treatments either continuous or were treated differently during vegetative growth and flowering. There were thus four treatments (WW, WD, DW, DD), each at two temperatures.

In the wet treatments, plants were watered when about $20 \%$ of the water held at field capacity had evaporated. In the dry treatments, plants were not watered until wilting of the lower leaves clearly indicated water stress. The moisture content of soil samples showed that this water stress approached PWP around most of the root system.

During vegetative growth, the watering of the wet treatments was altered to twice a day because of the following difficulties:

a. Much of the root system was in the top layer and depleted it of moisture much

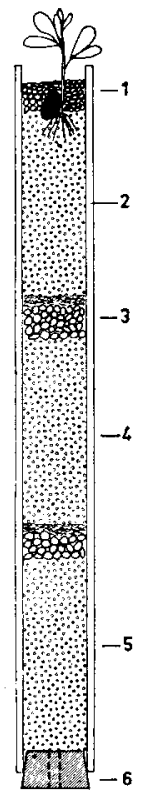

Fig. 1 Manner of filling tubes with compost; $1=$ coarse grit; $2=$ Perspex wall; $3=$ pebbles covered by glass wool; 4 and $5=$ compost $; 6=$ rubber stopper with $a$ hole in the centre. 
more than the lower layers. Thus the top layer could be around PWP before the average moisture content of the whole tube reached the predetermined level.

b. Growth of the plants in the wet treatments was thereby partially retarded, since much of the root system was subject to water stress, even though the two lower layers were near field capacity.

Hence plants in the wet treatment were watered twice a day. Surplus water was drained into cans below the tubes and used for subsequent waterings to replenish the soil nutrients.

\section{Plant material and phases of growth}

Seeds of Vicia faba were germinated in wet sand. When the second leaves started to expand plants were transferred to the tubes. The main root was excised about $3 \mathrm{~cm}$ below the seed so that secondary roots grew down uniformly through the layers.

The flowering phase was defined as starting when the first flower buds opened. Flowering proceeded as more nodes were differentiated on the stem, the habit of growth being indeterminate. Flowers were not self-fertilized and therefore fruit set only very rarely; plants continued to flower until the end of the trial.

The following water treatments were introduced in different sequences during the vegetative and flowering phases:

$\begin{array}{ccc}\text { Vegetative } & \text { Flowering } & \begin{array}{c}\text { Abreviation } \\ \text { for reference }\end{array} \\ \text { Wet } & \text { Wet } & \text { WW } \\ \text { Wet } & \text { Dry } & \text { WD } \\ \text { Dry } & \text { Wet } & \text { DW } \\ \text { Dry } & \text { Dry } & \text { DD }\end{array}$

The growth chambers

Two growth chambers were lit for a $12 \mathrm{~h}$ day during vegetative growth. Daylength was increased to $16 \mathrm{~h}$ during flowering to increase flowering. One chamber was kept at about $17^{\circ} \mathrm{C}$ and the other at about $25^{\circ} \mathrm{C}$. Total radiation measured at the surface of the continuously rotating tables on which the plants were placed, was $7.3 \times$

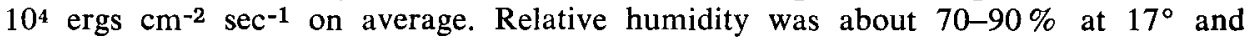
$50-70 \%$ at $25^{\circ}$.

\section{Results}

\section{General growth aspects}

Fig. 2 shows dry matter in roots and shoots against time. Each point represents the weight of a single plant. Variation between individuals was rather large but the general picture was consistent. The dry treatment reduced shoot growth to an increasing extent with time. Transfer from wet to dry treatment (WD) reduced shoot growth almost instantaneously. Conversely a change from dry to wet treatment (DW) instantaneously increased shoot growth.

In contrast the increase in root weight was not significantly affected. 
A. H. EL NADI, R. BROUWER AND J. TH. LOCHER
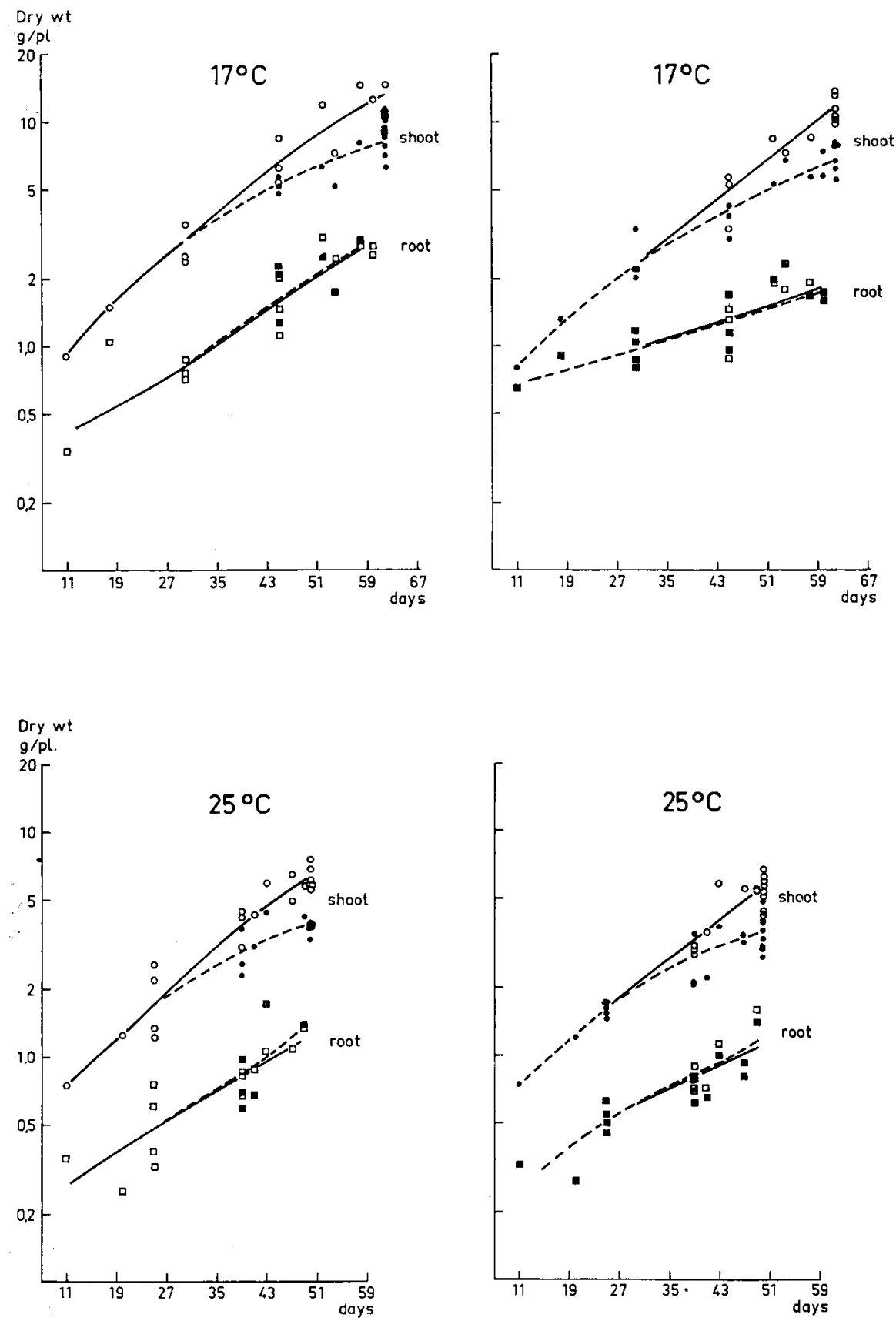

Fig. 2 Shoot and root weights of Vicia faba plants grown at either $17^{\circ} \mathrm{C}$ or $25^{\circ} \mathrm{C}$ in wet (-) and dry (-..-) soil. 


\section{Root to shoot ratios}

Cycles of water stress during the vegetative or flowering phase increased root to shoot ratio. It increased most when a dry treatment followed a wet treatment (WD). This general trend could be observed at both temperatures (Fig. 3). This figure shows a decrease in the root to shoot ratio shortly after emergence continuing slightly thereafter, as described in the literature. Onset of flowering had no special effect on root to shoot ratio in these non-fruiting plants.
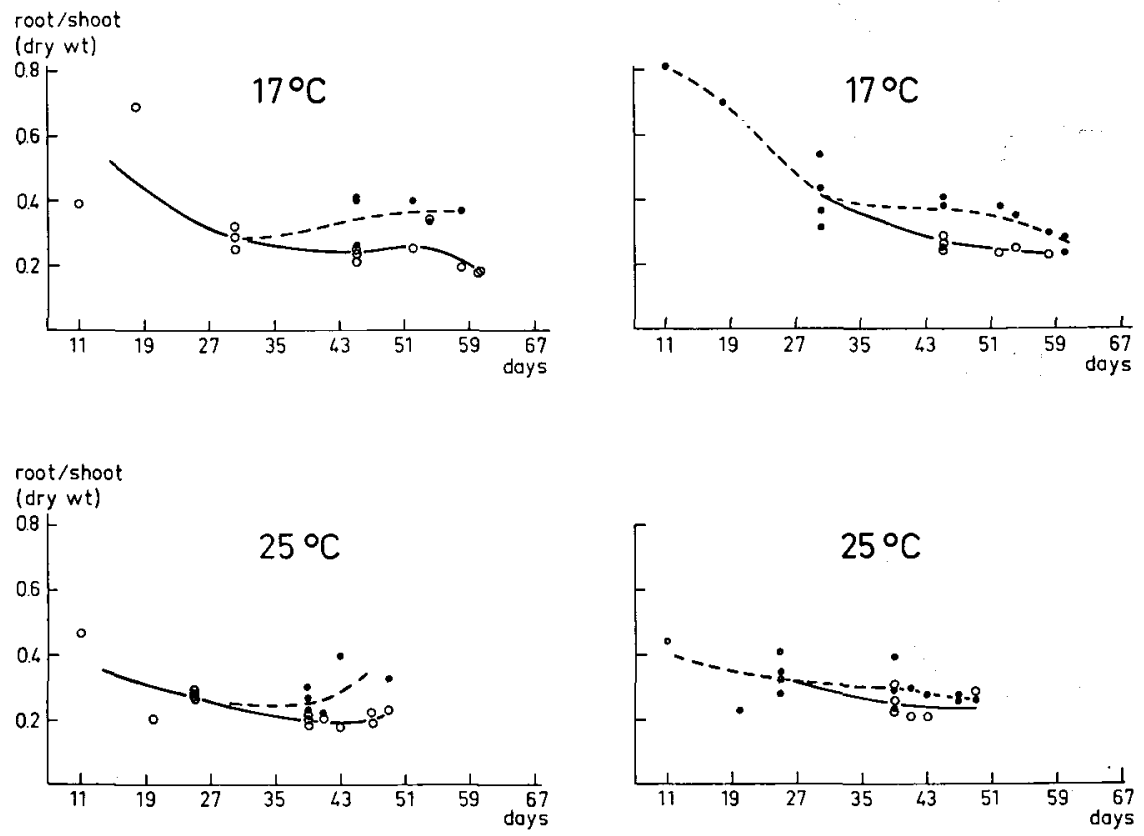

Fig. 3 Root to shoot ratios. Key als Fig. 2.

\section{Root distribution in relation to soil moisture}

Root dry weights in the upper soil layer and in the two lower soil layers are plotted in Fig. 4. A dry treatment continuously (DD) or after a wet treatment (WD) tended to reduce root growth in the upper layer and to increase root growth in the lower layers but there was a large scatter around the mean. However, total root weight was not affected (Fig. 2).

Compensatory growth is even more clearly demonstrated when the root weights found in the lower layers are expressed as percentages of the weights in the upper layer (Fig. 5). This effect of water stress on root distribution came out in the different combinations of water treatments. 

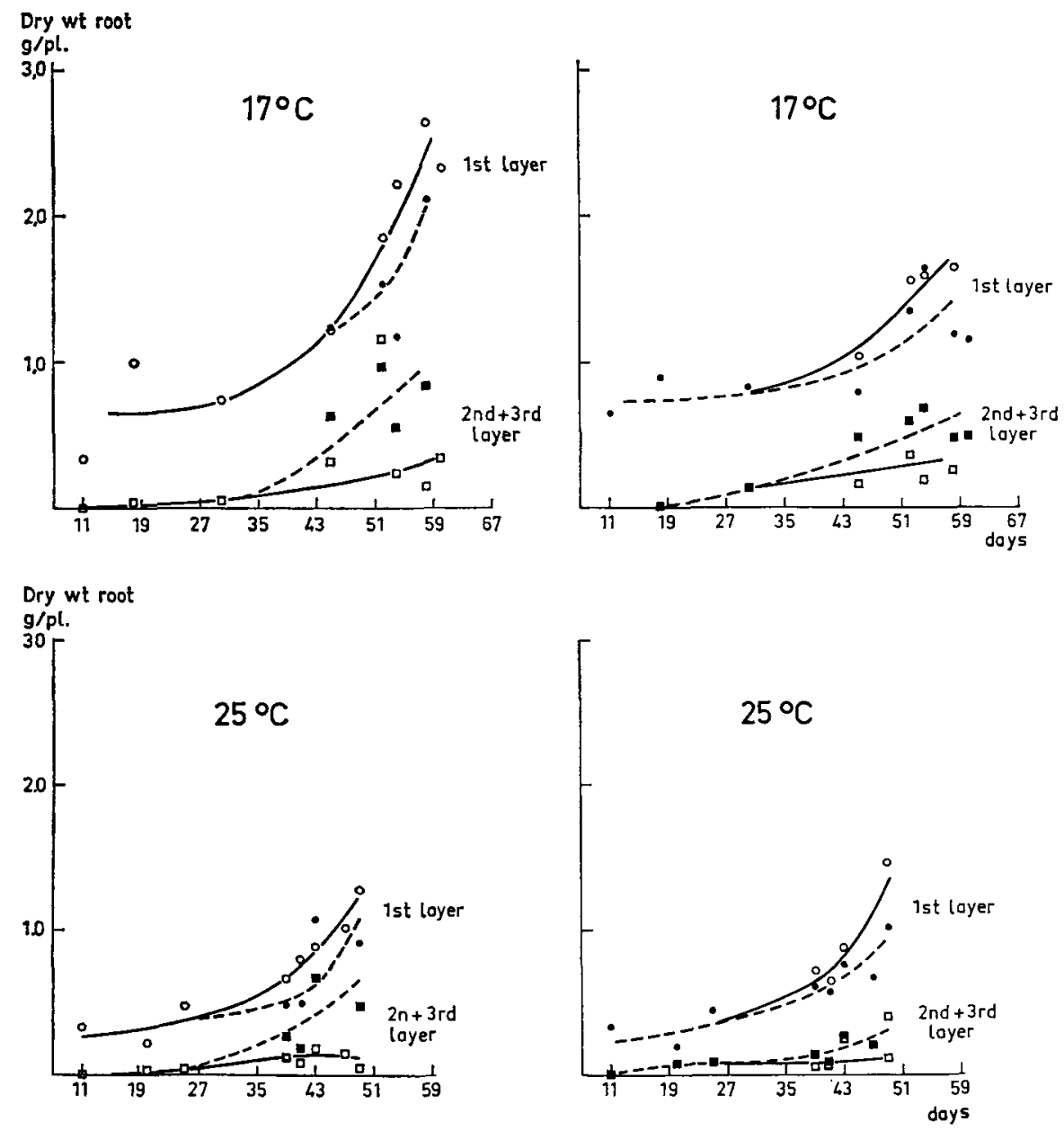

Fig. 4 Root weights in the upper $(0-20 \mathrm{~cm})$ and lower $(20-60)$ layers of soil.

\section{Transpiration rates}

Transpiration rates per day for plants grown in wet soil were compared with those grown in dry soil. Direct evaporational losses of water from the soil surface were measured in tubes without plants. Losses from tubes containing moist soil, covered by a thin layer of grit, were compared with losses from tubes containing dry soil. The losses from the moist surfaces were about $3.5 \%$ of the total evapotranspiration, whilst losses from the dry surface were less than $2 \%$ of the total evapotranspiration. Daily rates increased with size of plant (Fig. 6). In the dry treatment, water was readily available directly after watering. Transpiration rates increased after watering and then decreased steadily to low values during subsequent exhaustion. Expressed per unit shoot weight, transpiration rates of the dry treatment were higher than those of the wet treatment on days when they had similar water contents in soil (Table 1). 
$17^{\circ} \mathrm{C}$

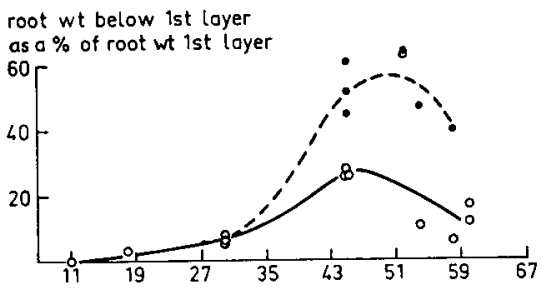

$25^{\circ} \mathrm{C}$

root wt below ist layer

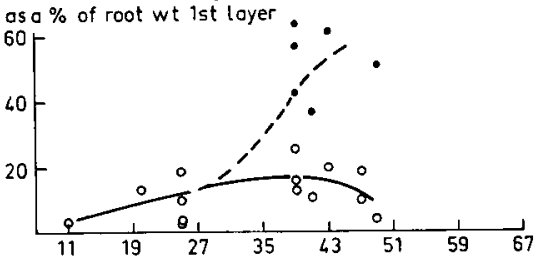

$17^{\circ} \mathrm{C}$

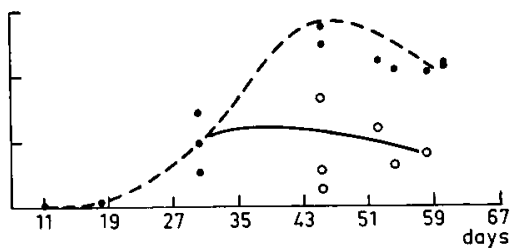

$25^{\circ} \mathrm{C}$

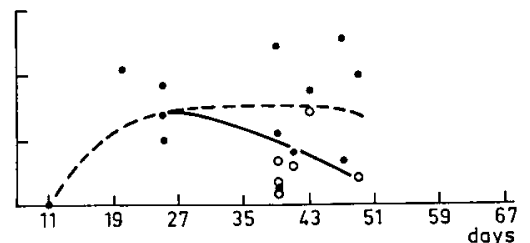

Fig. 5 Root weights in the $20-60 \mathrm{~cm}$ layer as percentages of the root weights in the 0-20 cm layer
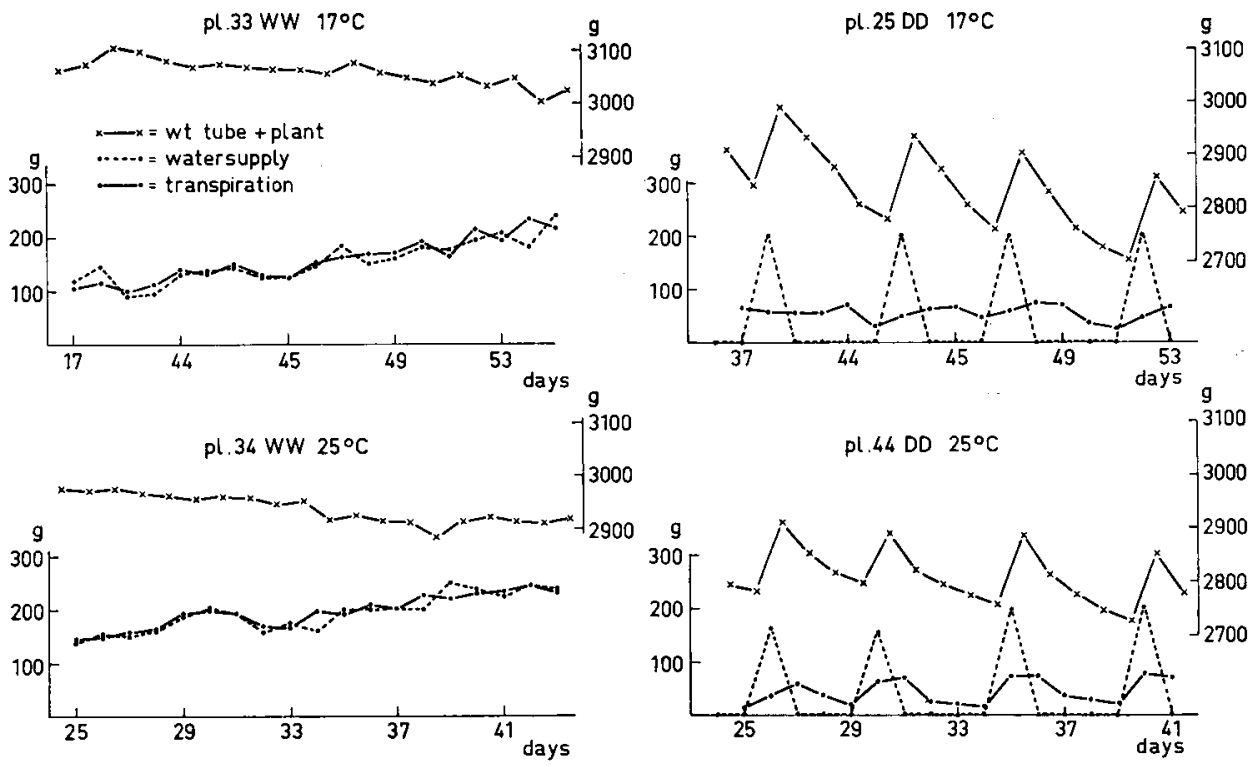

Fig. 6 Total tube weight $(x-\infty)$ ) (plants included) and rates of daily transpiration (.__ ) and supply (......) (gross supply minus drainage) 
Table I Transpiration rates over 24 hours expressed per gramme dry weight, shoot and root, of plants grown in wet soil $(W W)$ and of plants of the dry treatment after watering $(D D \rightarrow W)$

\begin{tabular}{|c|c|c|c|c|}
\hline \multirow[t]{3}{*}{ Soil } & \multicolumn{4}{|c|}{$\mathrm{g} \mathrm{H}_{2} \mathrm{O} g-1$ dry weight $24 \mathrm{~h}-1$} \\
\hline & \multicolumn{2}{|c|}{ shoot } & \multicolumn{2}{|c|}{ root } \\
\hline & $17^{\circ} \mathrm{C}$ & $25^{\circ} \mathrm{C}$ & $17^{\circ} \mathrm{C}$ & $25^{\circ} \mathrm{C}$ \\
\hline WW & 15 & 33 & 69 & 152 \\
\hline WW & 12 & 37 & 67 & 190 \\
\hline $\mathrm{DD} \rightarrow W$ & 19 & 43 & 74 & 155 \\
\hline $\mathrm{DD} \rightarrow \mathrm{W}$ & 22 & 46 & 73 & 163 \\
\hline
\end{tabular}

\section{Leaf elongation}

Leaf length was measured along the midrib for plants raised under the two levels of soil moisture at $17^{\circ} \mathrm{C}$. Daily increase in length of the youngest leaf from four plants are shown in Table 2.

Dry treatment generally reduced leaf expansion. Directly after watering leaves elongated as fast as with the wet treatment. The rate decreased, however, during exhaustion whereas in the wet treatment it was uniform.

Table 2 Daily rates of leaf expansion $(\mathrm{mm})$ measured along the midrib of the youngest leaf of 4 plants from wet $(W W)$ and dry $(D D)$ treatments at $17^{\circ} \mathrm{C}$. Wet treatments watered daily; dry treatments after third and sixth day

\begin{tabular}{lccccccc}
\hline & 1 & 2 & 3 & 4 & 5 & 6 & 7 \\
WW & 3 & 6 & 4 & 3 & 4 & 4 & 2 \\
WW & 5 & 3 & 4 & 6 & 5 & 3 & 3 \\
WW & 3 & 3 & 3 & 6 & 5 & 6 & 3 \\
WW & 3 & 5 & 3 & 5 & 3 & 3 & 2 \\
Average & 3.5 & 4.3 & 3.5 & 5.0 & 4.3 & 4.0 & 2.5 \\
DD & 6 & 4 & 2 & 3 & 4 & 1 & 3 \\
DD & 5 & 3 & 1 & 4 & 2 & 1 & 3 \\
DD & 4 & 6 & 5 & 5 & 3 & 0 & 5 \\
DD & 4 & 3 & 1 & 6 & 3 & 0 & 4 \\
Average & 4.8 & 4.0 & 2.3 & 4.5 & 3.0 & 0.5 & 3.8 \\
\hline
\end{tabular}

\section{Water content of the plant tissue}

At the end of each sampling the fresh and dry weights of shoots were estimated for comparison of growth. Water content of the shoot tissues was thus calculated for comparison between plants raised in different moisture conditions (Table 3).

The water content of plants adapted to dry soil was very. much the same as that of plants from wet soil. Changes in water content were observed directly after trans- 
SOME RESPONSES OF ROOT AND SHOOT OF VICIA FABA TO WATER STRESS

Table 3 Water content of the shoot tissue

\begin{tabular}{|c|c|c|c|c|c|c|c|c|}
\hline \multirow{3}{*}{$\begin{array}{l}\text { Water treatment } \\
\text { Phase } I\end{array}$} & \multicolumn{8}{|c|}{ Water content of the shoot tissue (\%) } \\
\hline & \multicolumn{4}{|c|}{$17^{\circ} \mathrm{C}$} & \multicolumn{4}{|c|}{$25^{\circ} \mathrm{C}$} \\
\hline & & $W$ & & $D$ & & $W$ & & $D$ \\
\hline $\begin{array}{l}\text { 1st harvest } \\
\text { 2nd harvest } \\
\text { 3rd harvest }\end{array}$ & & $\begin{array}{l}90.7(1) \\
90.7(1) \\
90.1(3)\end{array}$ & & $\begin{array}{l}90.1(1) \\
90.2(1) \\
90.3(3)\end{array}$ & & $\begin{array}{l}90.9(1) \\
90.3(1) \\
89.7(4)\end{array}$ & & $\begin{array}{l}90.1(1) \\
89.9(1) \\
88.4(4)\end{array}$ \\
\hline Phase II & $W W$ & $D W$ & $W D$ & $D D$ & $W W$ & $D W$ & $W D$ & $D D$ \\
\hline $\begin{array}{l}4 \text { th harvest } \\
5 \text { th harvest } \\
6 \text { th harvest } \\
7 \text { th harvest }\end{array}$ & $\begin{array}{l}89.0(3) \\
87.3(1) \\
87.5(1)\end{array}$ & $\begin{array}{l}88.5(3) \\
88.3(1) \\
87.4(1)\end{array}$ & $\begin{array}{l}87.4(3) \\
87.3(1) \\
87.3(1)\end{array}$ & $\begin{array}{l}88.9(3) \\
88.6(1) \\
86.2(1)\end{array}$ & $\begin{array}{l}87.7(3) \\
86.8(1) \\
86.8(1)\end{array}$ & $\begin{array}{l}88.7(3) \\
87.8(1) \\
87.2(1)\end{array}$ & $\begin{array}{l}86.3(3) \\
88.1(1) \\
86.1(1)\end{array}$ & $\begin{array}{l}87.1(3) \\
87.1(1) \\
86.1(1)\end{array}$ \\
\hline $\begin{array}{l}\text { Average } \\
\text { Leaves } \\
\text { Stem } \\
\text { Flowers }\end{array}$ & $\begin{array}{l}86.9(1) \\
87.6(1) \\
85.1(1) \\
87.9(1)\end{array}$ & $\begin{array}{l}86.4(1) \\
86.9(1) \\
84.9(1) \\
87.5(1)\end{array}$ & $\begin{array}{l}85.9(1) \\
86.1(1) \\
85.2(1) \\
86.3(1)\end{array}$ & $\begin{array}{l}87.6(1) \\
87.7(1) \\
87.6(1) \\
87.5(1)\end{array}$ & $\begin{array}{l}86.5(2) \\
87.5(2) \\
85.0(2) \\
87.1(2)\end{array}$ & & & $\begin{array}{l}85.9(2) \\
87.6(2) \\
85.8(2) \\
84.3(2)\end{array}$ \\
\hline $\begin{array}{l}8 \text { th harvest } \\
\text { I.eaves } \\
\text { Stem } \\
\text { Flowers } \\
\text { Average }\end{array}$ & $\begin{array}{l}87.2(2) \\
84.8(2) \\
85.6(2) \\
85.9\end{array}$ & & & $\begin{array}{l}86.9(2) \\
86.8(2) \\
85.7(2) \\
86.5\end{array}$ & & & & \\
\hline
\end{tabular}

$1=$ based on one plant $; 2=$ average of 2 plants ; $3=$ average of 3 plants $; 4=$ average of 4 plants.

fer to the dry conditions with a $\beta$-gauge measuring device $\left(\beta\right.$ source was $\left.{ }^{45} \mathrm{Ca}\right)$. Watering after a short drought increased water content within ten minutes and values remained high for about an hour (results to be published elsewhere).

\section{Discussion}

The drier the soil the deeper the roots grew. Soil moisture influenced root distribution in the profile but hardly affected root weight. Contrary to the generally accepted belief (Salter and Goode, 1967), bean roots continued to grow at the same rate during flowering (but no pods were developing) as in the vegetative phase. Trials in water culture confirmed this (Brouwer, in press).

Hence it is not flowering which reduces root growth but fruit setting and fruit growth. This assumption is in agreement with literature data which showed that the removal of flowers or young fruits did not induce changes in dry matter distribution between different plant organs (Brouwer, 1963).

Drought during fruit setting seemed more harmful than during vegetative growth as judged by a greater reduction in growth attributes directly related to final yield, e.g. total number of nodes and flowers (El Nadi, 1966). The root reduced the harmful effects of water stress by growing and branching deeper where the soil was less dry than in the upper layers. This finding is extremely interesting since it is generally accepted that plants are more sensitive to drought during fruit setting because the roots have almost stopped growing.

Presumably growth of roots in wetter layers of soil compensates less when root development as a whole is reduced due to fruiting. 
Various physiological explanations can be suggested for compensatory growth of roots in deeper soil layers in the dry treatments. The carbohydrates flowing down from the shoot are distributed over all growing parts of the root system. Parts growing most rapidly attract most of it. Growth rate depends on the supply and on external conditions. The root distributions in the trial do not indicate whether roots were hindered from growing in the lower layers of wet soil by excessive moisture and lack of air space or were hindered from growing in the upper layer of dry soil by moisture deficiency. Both explanations could be valid.

Although the morphology of the broad bean does not suggest a tendency for drought resistance, the moisture content of plants subject to severe cycles of water stress, was similar to that of plants raised with sufficient water. This suggests that reduction in growth was mainly a reduction in dry matter, but further investigations are necessary to support this view.

It is also interesting to compare the percentage reduction in transpiration rate with the percentage reduction in dry matter production over short periods of time. Wilting bean plants were able to restore their turgidity ten minutes after watering. This agrees with earlier work (El Nadi, 1966) when I detected an increase in stomatal opening fifteen minutes after watering bean plants subject to severe water stress.

\section{Acknowledgments}

The senior author is grateful to the Netherlands government for a research grant which enabled him to take part in this experimental programme and to the Director of the IBS, Wageningen, for providing research facilities.

\section{References}

Brouwer, R., 1963. The influence of the suction tension of the nutrient solutions on growth. Transpiration rate and diffusion pressure deficit of bean leaves (Phaseolus vulgaris). Acta bot. neerl. 12: $248-261$.

El Nadi, A. H., 1966. Effects of water stress on growth and flowering of the broad bean. Thesis, University of Nottingham.

Salter, P. J. \& Goode, J. E., 1967. Crop responses to water at different stages of growth. Research Review No. 2, Commonwealth Bureau of Horticulture and Plantation Crops. 